\title{
Duodenum and Ampulla of Vater Neuroendocrine Tumor Clinical Distant Metastasis TNM Finding v8
}

National Cancer Institute

\section{Source}

National Cancer Institute. Duodenum and Ampulla of Vater Neuroendocrine Tumor

Clinical Distant Metastasis TNM Finding v8. NCI Thesaurus. Code C135052.

A clinical finding about one or more characteristics of a duodenum and ampulla of Vater neuroendocrine tumor, following the rules of the TNM AJCC v8 classification system as they pertain to distant metastases. 